\title{
CHOICE OF LAW AND THE PROBLEM OF JUSTICE
}

\author{
Arthur Taylor von Mehren*
}

\section{INTRODUCTION}

Those who work in the field of choice of law are, at times, discouraged by the apparently intractable nature of the problems with which they must grapple. Intricate and subtle analyses are undertaken; ambiguities and uncertainties are painfully resolved. Ultimately, a result is reached, yet the solution is too frequently neither entirely satisfying nor fully convincing. ${ }^{1}$

The process of analyzing and deciding fully domestic cases is, of course, on occasion also difficult and the results reached are at times unsatisfying. Yet, overall, one is ordinarily less dissatisfied than with multistate cases. The deeper and more pervasive malaise engendered by these latter flows only partially from the relatively greater complexity of the analysis typically required; even where wholly domestic cases present a comparable order of difficulty, the solutions given in multistate cases are more likely to trouble one's sense of justice.

Is perhaps the problem of justice presented by multistate cases inherently more difficult? If so, why? What differences are there between the problem of justice in fully domestic situations and in multistate situations? Finally, can the standards of justice achieved in multistate cases be in the future brought closer to the standards of justice achieved in fully domestic cases? These problems and related issues are considered below.

For the legal order, the problem of justice is primordial. The most basic and universal test of legal rules and institutions is that they be formally just. Rules and institutions perceived as unjust are unstable and ultimately unacceptable. Justice is a complex concept: like cases should be treated alike; the legal consequences that attach to conduct should be understandable and

* Story Professor of Law, Harvard University.

1. Even that indomitable and indefatigable laborer in the conflicts vineyard, David Cavers -colleague, friend, and mentor-has apparently experienced moments of despair: “. . I find a flagging in my own zeal for detecting logical inconsistencies, mechanical rules, or even hard cases. The Restatement [First] begins to grow more tolerable simply because to most of the questions with which it deals, it provides ready answers." Cavers, Book Review, 56 Harv. L. Rev. 1170, 1173 (1943). This flagging of spirit was only transitory as Professor Cavers' writings in the 1960's and 1970's make clear. See note 21 infra. 
foreseeable. Rules and institutions must also express and advance values and purposes accepted by the community.

This conception of justice assumes that preferred values and purposes can be determined where disagreement exists or is possible. Until these preferences are authoritatively established, the justice of any given rule or institution is not formally established. A further implication is that legal rules and institutions must be known, or at least knowable, by the individuals for whose activities these rules or institutions have significance. Information must be available about the rules and institutions operative at any given time and, to the extent that the consequences of present action lie in a more or less remote future, the legal order must provide for stability and continuity. The imperatives of equal treatment, stability, and continuity require that rules be uniformly administered and that institutions operate in a coherent manner.

How can the uniform administration of rules and the coherent operation of institutions be assured? Disagreements about values and purposes can be resolved in several ways. Values and purposes may be seen as imposing themselves as a consequence of man's nature or of the culture and traditions of a given society. Alternatively, values and purposes can be determined by institutions charged with this task. The church, the monarch, the executive, the legislature, and the courts have in various degrees at different epochs discharged this function.

These values and purposes, once established, require uniform application in the administration of justice. How is this result to be achieved? Various solutions are theoretically possible but all Western legal orders, including codified systems, rely ultimately on a unified and centralized administration of justice. A single authority-the highest court-seeks to ensure the uniform application of legal rules and the coherent functioning of legal institutions. So that those whose activities are regulated by the legal order will be in a position to understand, by and large, the legal consequences of their actions, legislation and judicial decisions are published and an active and skilled legal profession is available. Legal rules are given considerable stability by the principle that legislative changes ordinarily have only prospective effect and by the proposition, expressed in various ways, that the courts, in particular the highest court, will only in exceptional circumstances change their views, once these have been stated, about the meaning and application of any given rule or principle. Finally, to ensure that legal rules and institutions remain responsive to the values and purposes held by the legal order they serve, procedures are provided through which unresponsive rules and institutions can be changed. The legislature has the primary responsibility for changing rules and institutions thought to be unwise or unjust. Comparable adjustments and determinations may, to a considerable extent, also take place judicially or administratively. Disagreement can, of course, exist within a society not only as to the justice or wisdom of a rule or an institution but also as to the change that is 
required. To the extent that such disagreements exist, they will be authoritatively resolved for the society by the legislature, the courts, or the executive. In some societies, values and purposes that are considered basic are given special protection in the sense that they can be changed only through special procedures-in particular, constitutional amendment or, though in most legal orders to a lesser extent, decision of a court charged with deciding constitutional questions.

From the foregoing it follows that justice can be fully achieved only where the legal unit coincides with the social or economic unit within which the given problem has arisen. In the modern world, this condition is fulfilled to a considerable extent as the relevant legal, economic, and social units are typically nation states. Great difficulties have, however, been experienced in the relatively recent past with the problem of justice when the effective legal unit was smaller than the significant social and economic units. For example, France and Germany did not resolve the problem until the French Revolution of 1789 and the creation of the German Reich in 1871, respectively, made effective and centralized administration of justice possible for all of France and all of Germany. Today, to the extent that contemporary economic and social life spills across the boundaries of nation states, the problem of justice remains, as we shall see, most perplexing.

The coincidence of legal, social, and economic units is important in still another respect for the problem of justice. Where such coincidence exists, legal rules and institutions have a claim to acceptance by those affected by the rule's application or the institution's operation as they are members of the community and participate in its social, economic, and political life. They can be taken, accordingly, to accept the values and purposes that inform these rules and institutions. To the extent that the persons affected belong to different communities, the basis for such an inference disappears, at least where the respective communities do not share the same values and purposes.

\section{II}

It follows from what has been said above that neither justice nor acceptance by those affected by a rule's application or institution's operation is fully achieved where the legal, social, and economic units involved do not coincide. In the modern world, the phenomenon of non-coincidence is typically the result of economic or social activities having significant relations or connections with more than one sovereign legal order. In such situations, rules are developed and applied and institutions operate without the possibility of resolving authoritatively such disagreements as may exist with respect to values and purposes. Furthermore, to the extent that the persons affected belong to different communities and these communities do not share the same values and purposes, the sociological and political bases for acceptance of a rule's 
application or an institution's operation are significantly diminished. In addition, these situations frequently require a choice between two principles of justice that are not opposed in fully domestic cases. These principles are that like cases be treated alike ${ }^{2}$ and that rules of law advance and express values and purposes accepted by society.

These shortcomings in the handling of multistate cases when compared with wholly domestic cases inhere in the multistate situation as does the necessity, only very rarely presented in domestic cases, of choosing between the two competing principles of justice noted, that like cases be treated alike and that rules of law advance and express values and purposes accepted by society. Choice-of-law methodologies must accept these inherent shortcomings. They can seek to reduce to the greatest extent possible the number of cases in which a choice must be made between the principle of equal treatment and that of advancing the community's purposes. Ultimately, however, each methodology faces the question of which principle to prefer where the two clash.

Having concluded that justice can rarely-if ever-be as fully achieved in multistate cases as in domestic cases, we can explore the problems of justice central to multistate cases. These are basically two: First, should one seek to avoid the choice between the principles of equal treatment and of advancing values? Second, if choice is unavoidable, which principle is to be preferred? These matters are considered seriatim.

\section{III}

Theoretically, choice between the two basic principles of justice in question-equal treatment and the advancement of values-should be avoided whenever possible. Absent other considerations, a result that satisfies both principles is more just than a result satisfying only one. Why then do not the traditional or classic approaches to the choice-of-law problem, as seen for example in the works of Beale and Savigny, ${ }^{3}$ address themselves in a central and sustained fashion to the problem of limiting, to the greatest extent possible, the need for such a choice?

At least two explanations can be ventured. In the first place, to the extent that traditional theories see choice of law as resulting from a kind of juristic inevitability there is nothing open for discussion. If the application of a choice-of-law rule does not advance the forum's values-or, for that matter, the values of any concerned community ${ }^{4}$ - that is unfortunate, but unavoid-

2. The most obvious form taken by violations of this principle is forum shopping.

3. See generally von Mehren, Special Substantive Rules for Multistate Problems: Their Role and Significance in Contemporary Choice of Law Methodology, 88 HARv. L. REv. 347, $351-53$ (1974).

4. For a discussion of situations in which traditional approaches produced this result, see $B$. Currie, Selected Essays on the Conflict of Laws 77-127 (1963). 
able. On the other hand, if a choice-of-law rule permits forum shopping, the responsibility rests with the other legal order's rule which is simply wrong.

Another and more satisfying explanation for the position taken by traditional theories is possible. Choice between the two competing principles of justice can be avoided where the several communities with which the case has significant connections in fact accept the same values and purposes; in such situations each can choose the same law and advance its values and purposes. But the only way to determine whether the concerned communities agree on values and purposes is to undertake a functional or instrumental analysis of the law of each community. The extensive comparative investigation thus required can be difficult and, on occasion, will face issues of great subtlety. In some cases the results will be ambiguous and engender uncertainty. Reluctance to undertake a difficult enterprise, and an understandable fear that the clarity and certainty of the solutions provided will suffer, go far to explain why, in principle, traditional methodologies make little effort to avoid the choice between the principle of equal treatment and that of advancing values. $^{5}$

In recent decades, especially in the United States, functional or instrumental approaches have been developed which undertake to analyze the potentially relevant laws of each concerned state. ${ }^{6}$ In cases of "false" or "no" conflict these approaches can avoid a choice between the principle of equal treatment and that of advancing values and purposes as neither principle need be violated if the other states concerned use the same methods. Of course, in order to achieve this advantage, functional approaches must be prepared to undertake more extensive and difficult investigations of foreign law than are normally required in traditional approaches. ${ }^{7}$ The practical question becomes, therefore, whether the improvement possible in the quality of justice administered in cases of "false" or "no" conflict is worth the complications and difficulties involved in determining whether a given case falls within one of these categories. One's answer to this question turns in considerable measure upon views about the feasibility and cost of the required comparative investigations.

5. A special and instructive example of the refusal by traditional systems to take advantage of the possibility of avoiding a choice between these two principles is found in these systems' pronounced tendency to reject the use of renioi. See A. von Mehren \& D. Trautman, The Law of Multistate Problems 512-16 (1965); von Mehren, The Renvoi and Its Relation to Various Approaches to the Choice-of-Law Problem, in XXth Century Comparative and Conflicts Law 380 (K. Nadelmann, A. von Mehren \& J. Hazard eds. 1961).

6. See generally von Mehren, Recent Trends in Choice-of-Law Methodology, 60 CornelL L. REv. 927 (1975).

7. For a general discussion of the comparative dimension of various choice-of-law methodologies see von Mehren, Choice-of-Law Theories and the Comparative Law Problem, 23 Aм. J. Coмp. LAw 751 (1975); von Mehren, L'apport du droit comparé à la théorie et à la pratique du droit international privé, 29 ReVue internationale de DROIT COMPARÉ 493 (1977). 
I V

No choice-of-law methodology can harmonize the principles of equal treatment and of advancing values in all cases. Accordingly, every conflicts approach must decide which principle is ultimately to be preferred.

Theoretically, the principle of equal treatment should, where a choice must be made, perhaps be preferred to the competing principle of advancing values. In private-law contexts it is generally more important to preserve equality between the parties by regulating the controversy in the same way regardless of the forum in which the litigation proceeds than to advance the purposes of one of the concerned states particularly since, by hypothesis, those of another concerned state must be frustrated. In addition, results reached by methods that provide equal treatment have a stronger claim to acceptance by all the parties than do results reached by methods that advance instead a given state's purposes.

A theoretical preference for the principle of equal treatment may disappear, however, in the face of the difficulties encountered when one seeks to realize the principle in practice. Such treatment can be assured only if a uniform system of choice-of-law rules is accepted by all the states concerned and this system is uniformly administered. Some progress in the direction of uniform rules has been accomplished through international conventions such as those prepared by The Hague Conference on Private International Law. However, internationally accepted rules administered by an international court remain, for the most part, utopian goals. In the absence of such rules and such a court, can the principle of equal treatment be realized in practice?

Traditional theories of choice-of-law sought to achieve equal treatment by suggesting that, in the nature of the juristic universe, certain propositions and results are inevitable. Thus Beale in his vested rights analysis argued from the proposition that law is territorial in nature to the conclusion that the law of the place where the last relevant event occurred regulates the given transaction or occurrence. ${ }^{8}$ And Savigny, deducing from the nature of a given legal situation its Sitz or natural seat, asserted that the law of that jurisdiction would govern. For example, the seat of a contractual obligation is, in principle, the place of performance and that law accordingly regulates questions respecting the obligation's substantial validity. ${ }^{9}$ The fatal difficulty with efforts of this type to ensure uniform rules uniformly administered is that the conclusion drawn is not inevitable. The fact that a contract is signed in state $A$ or has its

8. For example, in the case of a contract the law of the place of making (contracting) governs. See 2 J. Beale, a Treatise on the Conflict of Laws 1091 (1935).

9. See \& F. Savigny, System des Heutigen Römischen Rechts $\S \S 348,370$ (1849); F. Savigny, A Treatise on the Conflict of Laws, and the Limits of Their Operation in Respect of Place and Time $\S \S 348,370$ (trans. by Guthrie, 2d ed. 1880). 
Sitz there does not demonstrate that state A's views respecting the contract's validity must be accepted by all other states. In the legal universe, relationships of cause and effect depend significantly upon contingent and variable judgments respecting values and purposes. Appeals to juristic necessity are always misplaced.

In the absence of internationally accepted and administered rules and of juristic necessity how does the principle of equal treatment fare in practice? In theory, states may well be prepared to subordinate their particular policies if forum shopping can be avoided. But there are enormous practical difficulties in the way of achieving the required uniformity in choice-of-law rules and in their administration. In view of the difficulties and the related suspicion that in reality equality of treatment will not be secured, the alternative principle of advancing values becomes increasingly attractive. A forum proceeding on this basis can at least be sure that certain of its purposes are being served. Unlike traditional methodologies, the risk is not run that neither equality of treatment nor advancement of values will be achieved.

To the extent that the foregoing analysis is accurate, only an illusory choice exists between the two principles of conflicts justice. A preference for equal treatment cannot be realized in a systematic and coherent fashion. In practical terms, the alternative to the advancement of values is in many cases not equality of treatment but unequal treatment combined, on occasion, with non-advancement of values. Although simplicity and ease of administration may still argue for traditional methods, functional or instrumental methods may seem more attractive because they can advance in practice at least one principle of justice and sometimes both. In this perspective, the rise in recent decades of functional or instrumental analyses is entirely understandable.

In single-state cases and in cases of "false" or "no" conflict, no problem arises as to the state whose values are to be advanced. In cases of true conflict, however, the state or states must be selected. The need to select means that the results can not be as just as those reached in single-state cases or in multistate cases that do not present a true conflict. And a troublesome problem of choice is also presented. Essentially two solutions to this problem are possible. The values can be those of the forum (assuming that it is concerned on the issue) or those of another concerned state. What considerations determine the choice to be made here by a functional approach?

Several arguments can be advanced for the position that the principle of advancement should be conceived in terms of the forum's values and purposes. Considerations of simplicity and ease of administration support this solution. In particular, the problem of assessing the purposes and policies held by other communities is largely avoided and a clear rule is provided for resolving the problem of choice among conflicting values and purposes. For these reasons, among others, Professor Currie insisted that the forum's rule 
should be applied whenever there is "a legitimate basis for the assertion of an interest in the application" of "the governmental policy expressed in the law of the forum." 10

Although this solution offers certain practical advantages, another approach has considerable attraction from the perspective of conflicts justice. Essentially automatic application of forum law in cases of true conflict often results in a self-serving parochialism; the views held by other states are ignored in situations where, had they been those of the forum, they would have been given effect. Cannot this self-serving parochialism, a temptation for all choice-of-law theories that are in some significant sense functional, ${ }^{11}$ be avoided and a higher quality of conflicts justice be assured by approaching cases of true conflict as follows: The clash of values or policies that has arisen within the ad hoc community of concerned states is to be resolved not by considering what value or policy of the forum can be advanced but rather by determining how the forum would, in general, resolve the clash in question. The most obvious and general basis for making this determination is reasoning by analogy from the results reached in wholly domestic situations involving comparable clashes. Multistate situations involving true conflicts would thus present, just as do analogous domestic situations, the problem of deciding which among conflicting policies are, in general, to be preferred.

Both the temptations of self-serving parochialism and the operation of a functional approach of the type just proposed can be illustrated in a discussion of the New York Court of Appeals decision in Neumeier v. Kuehner. ${ }^{12}$ A New York resident picked up an Ontario resident in Ontario; the guest's journey ended there in a fatal accident. The guest's estate unsuccessfully sought to recover damages from the driver's estate in the New York courts. A line of decisions, beginning with Babcock $v$. Jackson,$^{13}$ had established that a New York resident, invited by a New York driver in Ontario and there involved in an accident, could recover in a New York action although Ontario had a so-called "guest" statute barring, or limiting, a guest's right to recover. The Neumeier decision, upon one possible reading of the implicated New York and Ontario policies, squarely raises the question whether, accepting the reasoning and results of the line of cases beginning with Babcock, the fact alone that the victim guest is an Ontario rather than a New York resident justifies application of the Ontario statute. ${ }^{14}$

10. Currie, supra note 4, at 183. Currie would exercise "restraint and enlightenment in the determination of what state policy is and where state interests lie." $I d$. at 186 . For a general discussion of Currie's views, see von Mehren, supra note 6, at 936-41.

11. Thus, an approach that masked its functionalism behind the rhetoric of a traditional approach can be as parochial and self-serving as an explicitly instrumental analysis.

12. 31 N.Y.2d 121, 286 N.E.2d 454, 335 N.Y.S.2d 64 (1972) (6-1 decision).

13. 12 N.Y.2d 473, 191 N.E.2d 279, 240 N.Y.S.2d 743 (1963) (5-2 decision).

14. In Neumeier, unlike Babcock, the trip originated in Ontario. This fact would not, however, 
From New York's perspective, the New York defendant's claim is stronger than that of the Ontario plaintiff as no New York interest in compensating a resident or his estate is present. Looking at the situation from Ontario's point of view, it is arguable that Ontario would, for the given case, wish to have its resident or his estate compensated. (The argument rests on the proposition that Ontario, in fully domestic situations, has subordinated a compensation policy to a policy of protecting insurance companies and their policyholders against possibly fraudulent claims. As this latter Ontario policy does not reach the case in question since New York insurance is involved, Ontario's domestically subordinated compensation policy should be given effect. Of course, if Ontario's guest statute has other purposes-for example, if Ontario considers it inappropriate for a guest or his estate to sue a host-the case is to be viewed as one of no conflict. $)^{15}$ On the view that the policy which informs the Ontario guest statute does not reach to the Neumeier situation, the decision refuses to give effect to a relevant Ontario compensation policy benefiting an Ontario party where a comparable compensation policy, asserted by New York in favor of a New York party, would be given effect. New York thus maximizes the interests of its own residents, although this entails in the Neumeier case the subordination of a compensation policy, held in the event by another jurisdiction, which New York prefers over the countervailing policy of protecting insurance companies and their policyholders against possibly fraudulent claims when the clash occurs in a fully domestic context.

For those who in applying the principle of advancement do so in terms of relevant forum policies, the result reached by the New York Court of Appeals in Neumeier is clearly correct unless one is prepared to include among forum policies a multistate policy such as evenhandedness. ${ }^{16}$ However, if the principle of advancement is applied in terms of the policies held by all the concerned states and the forum is to advance the policy or policies that it prefers when a comparable clash occurs in a fully domestic case, the Ontario plaintiff prevails unless the analysis of Ontario's policies proposed above is incorrect. In resolving the problem of the host's liability to guests for fully domestic situations, New York subordinates a policy of protecting insurance companies and hosts to a compensation policy. When a multistate case presents the same policy configuration, New York accordingly should prefer the same policy even though, in the event, the policy is held by Ontario.

An approach prepared to subordinate the forum's policy in such cases meets the objection that, in practice, functional methods with their emphasis

have led to the application of the Ontario statute if the guest had been a New York resident. Tooker v. Lopez, 24 N.Y.2d 569, 249 N.E.2d 394, 301 N.Y.S.2d 519 (1969) (4-3 decision).

15. For a full discussion of possible Ontario and New York policies, see Trautman, $A$ Comment [on Kell v. Henderson], 67 Colum. L. Rev. 465 (1967).

16. See A. von Mehren \& D. Trautman, supra note 5, at 255-63. 
on advancing values end up applying forum law whenever there is any possible basis for doing so. In deciding which of clashing policies to prefer, decisive weight would be given not to the forum policy relevant in the particular multistate case-for example, to the protection of local insurance companies and local hosts-but rather to the forum's general view as to how the clash in policies presented should be resolved. Thus a state that allowed a guest to recover under general tort principles in domestic situations should prefer the policy of compensation over host and insurance company protection in multistate guest cases involving a clash between these policies. Had the New York Court of Appeals done so in Neumeier, it would have done all within its power to achieve evenhandedness and to avoid a clash between the two basic principles of conflicts justice.

One further aspect of conflicts justice remains to be considered. In the discussion above ${ }^{17}$ on the clash between the principle of equal treatment and that of advancement of values in cases of true conflict, one problem was not explored: Is there any way in which a functional or instrumental approach that does not accord an automatic preference to any relevant policy held by the forum can avoid-or minimize-this clash? Can procedures be developed to reconcile in cases of true conflict these two principles of justice?

Reconciliation is possible to the extent that true conflicts are resolved by reference to a shared, and uniformly administered, norm or standard. Again the root of the difficulty is the lack of uniform rules administered by a supra-national authority and the consequent need to find surrogates.

Three different types of procedures have been proposed. One tries to achieve agreement as to which state's position as to priorities among clashing policies should prevail in view of each state's connections with the matter in litigation; another seeks consensus as to the types of policies to be preferred; a third proposes to compromise the clashing policies. ${ }^{18}$ Most efforts to deal with the problem adopt either the first or the second approach. Thus priorities are established by evaluating the significance or intensity of each state's concern for the issue to which the clash of policy relates. ${ }^{19} \mathrm{Or}$ appeal is made to widely held conceptions of justice, to the "better law," or to the views gen-

17. See p. 31 supra.

18. For a general discussion, see von Mehren, supra note 3 .

19. For example, Restatement (Second) of the Law, Conflict of Laws (1971), in stating in $\S 145$ a general principle for choice of law in the field of tort, speaks of the "local law of the state which, with respect to ... [the] issue, has the most significant relationship to the occurrence and the parties ...." A comparable formula-"the most significant relationship to the transaction and the parties..."-is used in $\$ 188$ to determine the law governing an issue in contract in the absence of an effective choice by the parties. Section 6, Choice-of-LaW Principles, gives principles in terms of which significance is to be evaluated. 
erally held by civilized nations. ${ }^{20}$ Finally, principles of choice or preference are developed on the assumption that modern societies share, for the general run of situations, certain values and are, accordingly, prepared to subordinate others that may be preferred in the particular case by a concerned state in order to advance, overall, both generally preferred values and the ideal of uniform and disinterested solutions to conflicts problems. ${ }^{21}$

Each of these procedures seeks to avoid the parochialism that tempts functional methods. Each also has some potential for reconciling the principles of advancement and equality of treatment. Thus, the test of "significant relationship" used by the Second Restatement encourages a forum to yield when its concern is marginal or when not to yield would be highly disruptive for the interstate or international activities in question. Professor Cavers' principles of preference seek to contribute to equality of treatment and to decisional harmony: The forum undertakes "to adhere to a principle of preference in the hope, but not on the condition, that it will provide a mutually acceptable scheme of accommodation for laws of the same general type as are involved in the case before it." 22

Each of the foregoing procedures could be analyzed in detail and its theoretical and practical advantages and disadvantages considered. However, in the context of efforts to reconcile the principles of advancement and of equality in cases of true conflict, the principal observation to be made is that a reasonable degree of reciprocity can not be guaranteed for those situations where another state's law is selected. The forum is asked to forego a present application of its policy in order to ensure decisional harmony and, presumably, the application by other states of its views in certain future cases of true conflict. Unfortunately, it is very difficult in practice to obtain this degree of cooperation and coordination among sovereign states. The forum is tempted to prefer a present advantage--the advancement of its policy in the instant case-to the contingent future advantage that present self-denial offers. In addition, the forum may well fear that others will engage in freeloading. Finally, even with the best will in the world, unless general agreement exists among the sovereign states as to the methods by which the principles of equality and of advancement are to be reconciled, little can be achieved. Here

20. A leading advocate of the "better-law" approach is Professor Leflar. See R. LEFLAR, American Conficts Law $\$ 109$ (1968). The approach has found a degree of explicit judicial acceptance. E.g., Clark v. Clark, 107 N.H. 351, 222 A.2d 205 (1966); Milkovich v. Saari, 295 Minn. 155, 203 N.W.2d 408 (1968) (Ontario driver and Ontario guest; car registered in Ontario and trip begun there; accident in Minnesota; recovery allowed under Minnesota law).

21. The originator and leading proponent of principles of preference is Professor David Cavers. He first developed the idea in the The Chotce-of-Law Process (1965). See also Cavers, Contemporary Conflicts Law in American Perspective, in 131 ACadémie de Droit International de LA HAYe, 1970-III Recueil des Cours 75, 151-62; Cavers, The Value of Principled Preferences, 49 Texas L. Rev. 211 (1971).

22. D. Cavers, The Choice-of-Law Process, supra note 21 , at 132. 
again, the fact that in multistate situations the legal unit is smaller than the economic or social unit in which the problem has arisen creates difficulties that defy full solution.

A third and quite different type of procedure, which may present certain advantages, has been proposed with a view to reconciling the principles of equality and of advancement in cases of true conflict. The suggestion is that, in those cases, the values held by each concerned state should be compromised. In some cases this compromise would be on the basis of equal respect; in others, rules would be applied only to the extent that, on the actual facts, the rule's underlying policy so required..$^{23}$ In domestic law, subordination of certain policies in favor of other policies is much more usual than is compromise of conflicting policies. However, examples of the latter can be found in domestic law. For example, workmen's compensation schemes recognize strict liability but, in return, limit compensation to scheduled amounts. And, in many legal orders, the doctrine of comparative negligence apportions loss between the parties on a sliding scale of percentages.

But traditionally Western jurists have, in principle, opposed the compromising of conflicting views or policies in the articulation of private-law rules and in the administration of these rules in discrete cases. Where the choice is inescapable, justice is ordinarily taken to require the delineation and vindication of generalized and abstract principles rather than the advancement of harmony in the human relations at stake. ${ }^{24}$ Accordingly, in the administration of justice full effect is to be given a party's claims if they are established; a plaintiff ordinarily receives all or nothing at all. ${ }^{25}$ Thus, the common law sees the plaintiff's contributory negligence as a bar to recovery rather than as a basis for reducing the damages to be awarded. Of course, as the three examples that follow illustrate, the implied rejection of compromise was never complete. The law of delict of many European countries long ago adopted the idea of comparative negligence under which fault-or loss-is apportioned according to the degree of fault. ${ }^{26}$ The United States Supreme Court in the 19th century accepted for admiralty matters the rule that when a collision is due to the fault of both vessels, the total damages are shared equally. ${ }^{27}$ Finally, the Court recently replaced the "divided-damage" rule by the degree-of-fault rule now almost universally used for admiralty matters. ${ }^{28}$

23. See generally von Mehren, supra note 3 .

24. For a non-western society's view of this problem, see von Mehren, The Legal Order in Japan's Changing Society: Some Observations, 76 HARv. L. REv. 1170,1174 (1963).

25. Cf. von Mehren, Some Reflections on Japanese Law, 71 HARv. L. Rev. 1486, 1496 (1958).

26. For France, see A. von Mehren \& J. Gordley, The Civil Law System 658-59 (2d ed. 1977); for Germany, see BGB (Civil Code) $\S 254$. See generally F.H. Lawson, Negligence in the Civil Law 53-59 (2d ed. 1975).

27. See G. Gilmore \& C. Black, The Law of Admiralty 492 (2d ed. 1975).

28. United States v. Reliable Transfer Co., 421 U.S. 397 (1975). 
When judicial activity is in question, the view that justice is ordinarily served by a choice among, rather than a compromise of, competing views and principles is reinforced, where the principle of separation of power obtains, by another consideration: compromising policy conflicts may be seen as a peculiarly legislative function and thus an improper task for courts.

A view of justice that in principle prefers choice among conflicting views and policies, with the consequence that some are fully vindicated and others completely subordinated, is normal-perhaps inevitable-where law is seen as ultimately emanating from one god or one nature. It is supportable-but not inevitable-where law is viewed as having its source in one sovereign. Accordingly, even though a divine or a natural source of law is no longer generally accepted, the Western view of justice derived from Greek thought and the Judaic-Christian tradition can be maintained when, as in wholly domestic situations, we are in the presence of but one sovereign. However, in multistate cases-except in an essentially formal sense (irrelevant to the issue under discussion) emphasized by such theories as Cook's "local law" analysis ${ }^{29}$ - several sovereigns are in the picture.

The assertion that justice in multistate situations normally requires the vindication of generalized and abstract principles implies that, in the final analysis, the law for the ad hoc community to which the multistate situation relates has, in some significant sense, its source in a universal god or a natural order. If a unitary source is not posited, compromises-designed to take competing views and policies into account and to advance harmony within a multistate order-can hardly be viewed as necessarily or inherently unjust. On the contrary, compromise as a principle of justice becomes understandable and attractive.

The objection remains, of course, that the striking of such compromises is essentially a legislative function. But this objection loses considerable force when one bears in mind that issues which arise only occasionally and within transitory multistate orders are not likely to engage the attention of the legislative bodies of the sovereign states involved. Moreover, these bodies would presumably find both difficult and uncongenial the inquiry and analysis often required to resolve these multistate problems. Thus, when the administration of justice in multistate cases is in question, the task of adjusting and compromising conflicting views and policies is arguably one for the courts even though they will, of course, encounter difficulties in discharging it.

Compromising clashes of policy that occur in cases of true conflict involves the development of special substantive rules for these multistate situations. In its most generalized form, where two concerned states hold conflicting policies such a rule would give half a loaf to each. No shared basis for resolving the

29. For a discussion of Cook's views, see von Mehren, supra note 6, at 930-31. 
conflict being available, the disagreement is compromised with equal weight accorded the views of each state. The cause of equal treatment is thereby advanced, particularly if the resulting special substantive rules are only utilized where all the concerned states accept in principle the approach, a fact relatively easily ascertained. ${ }^{30}$

Special substantive rules are not possible where the differences in values and purposes at issue are so fundamental as to make compromise unthinkable. Nor is the approach feasible where, in its nature, the issue requires a unitary solution. An example of both phenomena is furnished in some contexts by differences in views respecting monogamous and polygamous marriage. The difference in values and attitudes can be too great to permit a compromise. Thus, so far as marital relations are concerned, an on-going marriage could hardly be monogamous for one spouse and polygamous for the other, or monogamous during certain time periods and polygamous during others. (For questions of support and inheritance, on the other hand, a compromise between monogamy and polygamy is feasible. ${ }^{31}$ ) Where a guest sues after an accident to recover from the driver of the car in which the guest was riding, a true conflict of views among the concerned legal orders could be compromised. If one concerned state denied all recovery to the guest while the other permitted normal tort recovery, it might seem fair, for example, to allow the guest to recover one-half of the damages suffered.

It is instructive to discuss the use of special substantive rules in connection with the case of Cipolla $v$. Shaposka. ${ }^{32}$ A Delaware host, driving in Delaware a car there registered and insured, injured his guest passenger, a Pennsylvania domiciliary. Delaware had a guest statute protecting hosts while Pennsylvania permitted guests to recover under ordinary tort principles. The majority of the Pennsylvania Supreme Court found a true conflict but held the Delaware statute applicable because "Delaware's contacts are qualitatively greater than Pennsylvania's and... [Delaware] has the greater interest in having its law applied" and because "it seems only fair to permit a defendant to rely on his home state law when he is acting within that state." 33 The latter argument is persuasive, at least to the extent that the defendant was not protected by insurance. Where insurance coverage exists, however, the reliance-expectation argument loses some force and resolution of the true conflict is more difficult. (It is probably not feasible for American forums to distinguish between the handling of a case for choice-of-law purposes depending upon the existence or extent of insurance coverage; the American jury is not enti-

30. Of course, initially a jurisdiction would have to adopt the approach without assurance that other jurisdictions would follow. But, after some experience, each jurisdiction could insist on reciprocity.

31. See generally J.H.C. Morris, The Conflict of LAws 120-28 (1971).

32. $439 \mathrm{~Pa} .563,267$ A.2d 854 (1970).

33. Id. at 566-67, $267 \mathrm{~A} .2 \mathrm{~d}$ at 856 . 
tled to know whether the defendant is insured or for what amounts. Of course, this difficulty disappears in systems that do not use juries.) Justice Roberts, in dissent, agreed with the majority that the case involved a "true" conflict. ${ }^{34}$ However, invoking the "better rule of law approach," he would apply the Pennsylvania rule. ${ }^{35}$

If the argument of fairness to the defendant is considered persuasive, Cipolla can be viewed as a case of no conflict; Pennsylvania is prepared to subordinate its compensatory policy to its competing policy of protecting reasonable expectations and understandings. On the other hand, if Pennsylvania rejects the fairness argument either because it is intrinsically unpersuasive on the facts of the case or because the compensation policy is considered more compelling, a true conflict is presented. Delaware will prefer its relevant policy of protecting host drivers, as it does in wholly domestic cases presenting a generally comparable clash of policies, while Pennsylvania will prefer, as it does domestically, its compensation policy. In such a situation, a compromise solution, in the form of a special substantive rule partially accommodating the divergent Delaware and Pennsylvania views, could be attractive. For example, the plaintiff might be allowed to recover one-half of what Pennsylvania law provides. Alternatively, only certain items of recovery-for example, medical expenses and lost earnings during a convalescence period -might be allowed. Finally, if the problem of jury trial does not stand in the way, distinctions could be drawn on the basis of the existence and extent of insurance coverage. Thus full or partial recovery might be given, but only up to policy limits.

Bernhard \%. Harrah's $C_{\text {lub }}{ }^{36}$ presents another situation of true conflict where the use of a special substantive rule is worth considering. A tort action was brought in California against a Nevada tavern by a California resident injured in a highway accident in California. The tavern advertised in California. A resident of California drove to the tavern, was served alcoholic beverages, and became intoxicated. Driving back to her home, she negligently collided with the plaintiff's motorcycle. The court concluded that, at least where the defendant tavern had actively solicited California business, "California has an important and abiding interest in applying its rule of decision ... [and] that the [California] policy . . . would be more significantly impaired [than the Nevada policy] if such rule were not applied ...."37 Unless Nevada is prepared to take the same position-which is not likely-the only way in which decisional harmony could be advanced is to strike a mutually acceptable compromise. This might take the form, already suggested, of allowing half

34. Id. at 568,267 A. $2 \mathrm{~d}$ at 857 .

35. Id. at 573-78, $267 \mathrm{~A} .2 \mathrm{~d}$ at $859-62$.

36. 16 Cal. 3d 313, 546 P.2d 719, 128 Cal. Rptr. 215 (1976).

37. Id. at 323, 546 P. $2 \mathrm{~d}$ at 725-26, 128 Cal. Rptr. at 221-22. 
the normal California recovery. Viewing the situation overall, the principle of advancement of values is as effectively served by compromise as it would be by a solution in terms of subordination; at the same time, a result is reached that might well prove acceptable to both Nevada and California and thus satisfy the principle of equal treatment.

\section{VI}

The foregoing analysis of conflicts justice gives a basis for conclusions, already foreshadowed, of two different types. The first relate to whether the justice administered in conflicts cases can hope to approximate the standards applied in fully domestic cases. The second deal with the issue whether, from the perspective of potential for achieving justice, certain choice-of-law methods are to be preferred over others.

For reasons discussed above, it seems clear that, except perhaps in certain cases of "false" or "no" conflict, the standards of justice applied to fully domestic cases cannot be achieved in multistate cases. Even in cases that do not present a true conflict, the fact that the parties will ordinarily be from different states tends to reduce significantly the decision's claim to legitimacy. A further source of doubt in some cases is that lay thinking is often strongly shaped by the territorial connections of the total situation although analytically these may be largely irrelevant for a jurist deciding what law governs the issue before the court. ${ }^{38}$ The justice of a decision in a fully domestic case can never be challenged on such grounds and is greatly strengthened by the fact that the views of only one society need be taken into consideration. Finally, a court in a multistate case must undertake a process of analysis that is inherently more complex than that faced in a purely domestic case; to a greater or lesser degree, the court must take into account the rules and policies of foreign legal orders. ${ }^{39}$ Accordingly, the areas of possible doubt and ambiguity are larger. For these reasons, one who expects to achieve results in multistate cases that are as satisfying in terms of standards of justice and of party acceptability as those reached in purely domestic cases is doomed to disappointment. Perhaps the most satisfactory solution would be to render choice of law unnecessary by establishing supra-national rules administered by supranational agencies. But this solution engenders its own difficulties and is unlikely for historical and political reasons.

38. The New York Court of Appeals seemed to give some weight to this factor in those pre-Tooker decisions that took into account whether the place of the accident was "fortuitous" or "adventitious." E.g., Dym v. Gordon, 16 N.Y.2d 120, 209 N.E.2d 792, 262 N.Y.S.2d 463 (1965).

39. Additional complications are that policies not involved in single-state situations, e.g., the facilitation of multistate activity, must be taken into account and policy choices that arise only in multistate situations must be made. See von Mehren, supra note 6, at 936-39; von Mehren, Book Review, 17 J. Lecal Ed. 91,93 (1964). 
What conclusions are to be reached on the issue whether, from the perspective of conflicts justice, certain choice-of-law methods are preferable to others? For reasons that have been developed above, it appears that functional or instrumental approaches can achieve a higher quality of conflicts justice than is attainable by approaches that do not proceed functionally. Non-functional approaches emphasize the principle of equality; however, this ideal eludes them in practice with the result that neither equal treatment nor advancement of values is achieved on a systematic basis. Functional approaches, on the other hand, in a significant class of cases-those involving "false" conflicts-advance both ideals and, in cases of "true" conflict, at least advance values on a systematic basis.

There is, as has already been observed, considerable variation in the quality of conflicts justice that different functional approaches can provide. In particular, if a priority is given in principle to the advancement of forum values, the consequences for conflicts justice are problematical. The quality of conflicts justice produced by functional approaches that do not give such a priority can, it should be remarked, be still further improved if ways are found to reconcile in some measure the principles of advancement and equal treatment.

Finally, it must be remembered that discussion of choice-of-law methodology from the perspective of justice can not demonstrate that functional approaches are necessarily preferable to more traditional approaches. Considerations of practicality, of cost, and of administrability must be taken into account before any such conclusion would be permissible. However, advantages from the perspective of the problem of justice that functional approaches offer over more traditional choice-of-law methods at least explain why these latter are today challenged by the former. 